\title{
STALKING OCUPACIONAL: A TIPIFICAÇÃO DO CRIME DE PERSEGUIÇÃO PELA LEI 14.132/2021 COMO PUNIÇÃO PENAL AO ASSÉDIO MORAL
}

\section{Ângela Diniz Linhares Vieira*}

\section{RESUMO.}

O texto propõe a possibilidade da tutela penal ao trabalhador contra a violência perversa provocada pelo assédio moral através da leitura e análise da Lei 14.132/2021 que tipificou o crime de perseguição. Propõe-se num primeiro momento, abordar o conceito de Assédio Moral, para, num segundo momento, averiguar qual a tutela legal penal que existia no ordenamento jurídico brasileiro, quanto ao Assédio Moral, até a aprovação da Lei 14.132/2021. Por último, tercer-se-a considerações iniciais sobre o crime de perseguição e a sua possibilidade de aplicação quanto a perseguição provocada pelo Assédio Moral.

PALAVRAS-CHAVES. Stalking ocupacional. Assédio Moral. Crime de Perseguição.

\section{OCCUPATIONAL STALKING: THE TYPIFICATION OF THE CRIME OF STALKING BY LAW 14.132/2021 AS A CRIMINAL PUNISHMENT FOR BULLYING AT WORK}

\begin{abstract}
The text proposes the possibility of criminal protection to the worker against the perverse violence caused by moral harassment through the reading and analysis of Law 14.132/2021 that typified the crime of persecution. In a first moment, it is proposed to approach the concept of Moral Harassment, in order to, in a second moment, investigate the criminal legal protection that existed in the Brazilian legal system, regarding Moral Harassment, until the approval of Law 14.132/2021. Finally, initial considerations will be made on the crime of persecution and its possible application to persecution caused by Moral Harassment.
\end{abstract}

KEYWORDS . Bullying at work. Bullying. Stalking.

\section{INTRODUÇÃO.}

* Graduada em DIREITO pela UNIVERSIDADE FEDERAL DE GOIÁS (2008); Mestra em DIREITO AGROAMBIENTAL pela UNIVERSIDADE FEDERAL DE MATO GROSSO (2013); Estágio docência em Direito do Trabalho I (2013); Bolsista do Capes (2013 e 2014); Procuradora do Município de Barra do Garças (2015 e 2016); Professora da Faculdade de Ciências Jurídicas e Sociais Aplicadas do Araguaia (20142018); Pesquisadora da linha de pesquisa "Direitos Humanos e Cidadania", da Faculdade de Ciências Jurídicas e Sociais Aplicadas do Araguaia (2017).Professora convidada do Curso de Pós-Graduação em Direito Civil e Processual Civil da Faculdade FASIPE onde ministrou a disciplina Cumprimento de Sentença. Atualmente é professora do Instituto Cuiabá de Ensino e Cultura(ICEC) e doutoranda em Ciências Sociais pela Universidade do Vale do Rio Sinos. E-mail: adinizlinhares@yahoo.com.br 
O presente estudo analisa o assédio moral quando ele se tornou objeto de proteção, partindo da premissa de que a violação à saúde psíquica cometida por este, significa uma afronta aos direitos fundamentais do trabalhador.

Trata-se de matéria de relevo jurídico indiscutível e eminente, atentando-se não apenas para seus elementos configuradores, como também para o tratamento que lhe é conferido pela doutrina e jurisprudência brasileira.

O objeto deste trabalho circunscreve-se, num primeiro momento, abordar o conceito de Assédio Moral, para, num segundo momento, averiguar qual a tutela legal penal que existia no ordenamento jurídico brasileiro, quanto ao Assédio Moral, até a aprovação da Lei 14.132/2021. Por último, tercer-se-á considerações iniciais sobre o crime de perseguição e a sua possibilidade de aplicação quanto a perseguição provocada pelo Assédio Moral.ao regramento atual do meio ambiente do trabalho e de que forma a proteção à saúde mental do trabalhador se dará.

O tema em epígrafe tem sido desenvolvido recentemente por juristas brasileiros e estrangeiros, revestindo de inquestionável atualidade, de interesse doutrinário e prático marcantes.

A pesquisa será de natureza bibliográfica, pois se realizará a partir de registro disponível, decorrente de pesquisas anteriores, em documento impressos, como livros, artigos,teses, dentre outros.

Para a investigação serão usados os seguintes recursos técnico-metodológicos: fichamentos, resumos e relatórios a partir de leitura sistemática e atenta do referencial bibliográfico.

\section{ASSÉDIO MORAL COMO ESPÉCIE DE VIOLAÇÃO PSÍQUICA E SUA CARACTERIZAÇÃO NAS RELAÇÕES DE EMPREGO.}

\subsection{ELEMENTOS DO CONCEITO E MODALIDADES DO ASSÉDIO MORAL.}

Ressalte-se inicialmente que a expressão “ assédio moral” é, induvidosamente, a mais conhecida. Entretanto o fenômeno é também denominado como mobbing (Itália, Alemanha e países escandinavos), bullying (Inglaterra) harassment (Estados Unidos), harcèlement moral (França), ijime (Japão), psicoterror laboral ou acoso moral (em países de 
língua espanhola), terror psicológico, tortura psicológica ou humilhações no trabalho (em países de língua portuguesa).

Todavia, os primeiros estudos sobre o Assédio Moral partiram de ciências afetas à psique humana, de modo que essas disciplinas foram as responsáveis pela caracterização e denominação do fenômeno. O primeiro estudioso a problematizar o fenômeno foi o psicólogo do trabalho, de origem sueca, Heinz Leyman que, por consequência, foi o primeiro a denominá-lo.

O referido professor, originariamente, utilizou-se da expressão mobbing, palavra advinda da língua inglesa, derivada do verbo to mob e do substantivo mob. Verbo cuja tradução mais próxima para a língua portuguesa é molestar, cercar . O substantivo mob significa multidão ou coletividade em tumulto. Deste modo, Leymann sugere que mobbing diz respeito a uma conduta de molestar diante de multidão, com efeito, o agente agressor utiliza gestos insidiosos, zombarias contra o trabalhador diante de seus colegas.

Pioneiro nos estudos sobre o fenômeno em tela, Heinz Leymann define Assédio Moral como:

Por mobbing, entendem-se as ações repetidas e repreensíveis ou claramente negativas, dirigidas contra empregados de uma maneira ofensica, e que podem conduzir a seu isolamento do grupo no local de trabalho.(HIRIGOYEN, 2010, p.78)

Apesar de Heinz Leymann ser o primeiro nos estudos sobre assédio moral, MarieFrance Hirigoyen, vitimóloga francesa, é o maior nome do estudo acerca do fenômeno assédio moral, pois ela realizou um estudo integral entre teoria e casos concretos delineando com perfeição as características do terror psicológico, cuja definição é transcrita a seguir:

O assédio moral no trabalho é definido como qualquer conduta abusiva ( gesto, palavra, comportamento, atitude...) que atente, por sua repetição ou sistematização, contra a dignidade ou integridade psíquica ou física de uma pessoa, ameaçando seu emprego ou degradando o clima de trabalho.( HIRIGOYEN, 2010, p.17)

Através destes conceitos vê-se que o assédio moral já faz parte do rol de conflitos do mundo do trabalho, mas o ordenamento jurídico brasileiro não oferece uma legislação federal específica. Em face da ausência de previsão legal, coube à doutrina e à jurisprudência determinar um conceito capaz adequado à solução dos conflitos de interesse presentes nas reclamações cujo objeto jurídico seja a reparação por danos sofridos em decorrência do 
assédio moral. Em que pese tal conceituação, vale ratificar que ambas recorreram aos estudos em psicologia e medicina do trabalho.

Portanto, o assédio moral, também conhecido como terrorismo psicológico ou "psicoterror", é uma forma de violência psíquica praticada no local de trabalho, e que consiste na prática de atos vexatórios, humilhantes, degradantes e constrangedores, de forma sistemática e prolongada, cuja prática assediante, como veremos posteriormente, pode ter como sujeito ativo o empregador ou superior hierárquico (assédio vertical), um colega de serviço (assédio horizontal), ou um subordinado (assédio ascendente), com clara intenção discriminatória e perseguidora, visando eliminar a vítima da organização do trabalho (ALKIMIM, 2005, p.37).

Para melhor explicar o fenômeno do assédio moral, existem claramente, na atualidade, duas concepções diferentes sobre esse assunto:

a) a subjetiva (PAMPLONA FILHO, 2005);

b) a objetiva.(LIMA FILHO, 2009, p.36)

A primeira concepção - a subjetiva - leva em conta a intencionalidade do agente assediador como elemento constitutivo do assédio moral no trabalho, muito valorizada pela jurisprudência dos tribunais trabalhistas brasileiros, na medida em que leva em conta como elemento identificador da conduta do assediante, "a intenção de afastar o trabalhador do emprego", o que nem sempre ocorre, pois, pode perfeitamente ser reconhecido Assédio Moral mesmo quando não haja por parte do assediante nenhuma intenção de eliminar ou afastar a vítima do seu posto de trabalho.

A segunda concepção - objetiva - entende que a intencionalidade supõe na verdade um elemento acessório do conceito do assédio moral no trabalho, cuja concorrência não é indispensável para que possa se apreciar a sua existência. Quando se analisa o conceito de assédio moral dado pela psiquiatra e psicanalista, Marie-France Hirigoyen, anteriormente descrito neste trabalho, percebe-se que o assédio moral pode "ameaçar o emprego" como pode também "degradar o clima de trabalho", ou seja, a intenção de afastar o trabalhador do emprego não é o único elemento identificador da conduta do assediante.

Adotando a concepção objetiva de Francisco das Chagas Lima Filho e em uma visão mais simplificada pode-se dizer que o Assédio Moral é a sujeição do empregado a situações humilhante e vexatórias, reiteradas e prolongadas no tempo, produzidas por um superior 
hierárquico, um colega de trabalho ou até mesmo um subordinado, visando a sua humilhação e desestabilização emocional, cujos elementos constitutivos serão objeto do próximo tópico.

\subsubsection{Elementos constitutivos do conceito de assédio moral}

De acordo com a definição objetiva, pode-se distinguir entre elementos ou requisitos de caráter constitutivo, cuja ocorrência conjunta torna-se indispensável para se apreciar a existência do assédio moral, e elementos acessórios, ou seja, aqueles que ordinariamente aparecem nas situações de assédio moral, porém não se mostram imprescindíveis para a constatação do mesmo, que pode perfeitamente acontecer sem a sua presença.

Temos assim, duas espécies de elementos integrantes do conceito de Assédio Moral:

a) os elementos de caráter constitutivo, ou seja, imprescindíveis;

b) os elementos acessórios, que podem ou não se fazer presentes na conduta do agente assediante, conforme será demonstrado logo mais.

Os elementos constitutivos do assédio moral, como antes afirmado e de acordo com o conceito, aqui acolhido, constituem aqueles requisitos que necessariamente haverão de concorrer, de forma conjunta, para que se possa verificar sua existência.

São eles: sujeitos, condutas lesivas não desejadas suscetíveis de causar um dano (de natureza psíquica, física, patrimonial), afetação à dignidade da pessoa, reiteração de condutas e relação com o trabalho.

Esses elementos podem, na visão da doutrina aqui seguida, ser divididos em:

a) subjetivos, constituídos pelo sujeito ativo e passivo do assédio;

b) elemento objetivo, integrado pela conduta típica;

c) elemento teleológico, representado pela intencionalidade do agente agressor; e,

d) elemento organizacional, que diz respeito ao contexto sócio laboral.

Os elementos subjetivos serão os primeiros a serem analisados no próximo tópico.

\subsubsection{Elementos subjetivos.}

O fenômeno do assédio moral no trabalho em regra nasce no seio das relações laborais altamente regulamentadas e homogêneas, bem como em instituições conservadoras, 
nas quais possa existir pouca tolerância à diversidade e identidade compartilhadas entre seus membros. Por isso, de acordo com Lima Filho:

$\mathrm{O}$ assédio psicológico se faz mais presente em organizações relativamente fechadas, cuja cultura interna considera o poder e o controle como valores prioritários sobre a produtividade e eficá,cia.(LIMA FILHO, 2009, p.37)

Conforme o exposto, os sujeitos inseridos nesse tipo de conduta são o assediante (o sujeito ativo) e a vítima (o sujeito passivo) ou assediado, ainda que a relação não tenha, obrigatoriamente, caráter individual ou singular, na medida em que o assédio moral pode proceder de um coletivo, como na circunstância em que ele advém de vários colegas de trabalho de um mesmo nível profissional, podendo ainda afetar mais de um trabalhador, pois embora essa situação seja a mais rara, não é impossível de acontecer.

a) Sujeito ativo: também conhecido como o assediador que pode ocupar várias posições dentro da empresa, não precisa ser necessariamente um superior hierárquico, mas, se o for, a sua conduta implica, nesse caso, abuso de poder.

Os sujeitos ativos do assédio moral podem ser um subalterno que sonha em ocupar o cargo de chefe ou vários subalternos que tenham preferência pelo antigo superior hierárquico e pretendam desvalorizar o atual, ou, colegas de trabalho que tenham dificuldade de conviver com a diferença (mulher em grupos de homens, homossexualidade, diferença religiosa ou social) (HIRIGOYEN, 2010, p.70), e, por último, também se enquadram como sujeito ativo, o colega de trabalho que, com o espírito de competição, inimizade ou inveja, assedia seu companheiro de trabalho.

Há vários perfis traçados para o assediador, sob a ótica - e na linguagem - popular, entre eles: o mala-balão, bajulador do patrão e controlador dos subalternos; o pitt-bul, assim considerado o chefe perverso, agressivo que sente prazer em humilhar e não se sensibiliza ao despedir o empregado; o troglodita, que é aquele que se considera o dono da verdade, dita normas e todos devem respeitá-las, sem contestar; o tigrão, que se utiliza de indelicadezas como escudo de sua incompetência e precisa de plateia para presenciar seu comportamento e sentir-se temido e respeitado; o garganta, que não domina suas atividades, mas adora contar vantagem e desmerecer o subordinado mais preparado.

Inicialmente, o perfil do sujeito ativo é o de uma pessoa perversa (HIRIGOYEN, 2010, p.116) . Isso acontece, explica Alice Monteiro de Barros, porque a provocação que 
exerce sobre a vítima leva-a a ultrapassar os seus limites (BARROS, 2008, p. 924). A autoestima do assediador advém da humilhação dos outros. Em síntese, utiliza-se de um tom doutoral, dá a impressão de saber, usa palavras técnicas sem se preocupar com o sentido, demonstra uma erudição superficial e argumentos incoerentes (HIRIGOYEN, 2010, p.116)

A meta do assediador é aborrecer alguém mais fraco, cuja apreensão sujeita não só a vítima, mas também os outros empregados ao seu lado. Ele é assustador e, por isso a probabilidade de a vítima receber auxílio dos que a circunda é difícil. Ao proceder assim, porém, estes outros empregados transformam-se em cúmplices do assediador pela indiferença, pelo medo ou pela covardia (BARROS, 2008, p.924). Para o assediado o fundamental é o poder na organização, obtido por meio do controle e domínio dos outros.

Destaca a doutrina espanholao perfil de um tipo de assediador, pouco estudado, que é ocupante de alto cargo, inteligente, muito considerado na sociedade, mas com dose excessiva de vaidade e narcisismo que exige a tal ponto a entrega total do subordinado que acaba por suscitar-lhe terror psicológico. Ele adota uma estratégia de utilização e depois de destruição do outro, sem qualquer culpa.(GARCIA CALLEJO, p. 43)

Esse assediador é um perverso narcisista, além de egocêntrico, que precisa ser admirado, não suporta crítica. Gosta de controvérsia; não raro sustenta determinado ponto de vista em um dia e no dia seguinte defende ideias contrárias, exatamente para chocar ou para levar o outro a se expor. É considerado um psicótico sem sintoma. Ele se sustenta na insensibilidade. Desconhece o afeto, a tristeza e o luto, combate a decepção com a vingança premeditada e sem limites. É também sádico, pois alegra-se com o sofrimento alheio. (HIRIGOYEN, 2010, p.121)

Para findar, Alice Monteiro de Barros, acrescenta que:

Afirmam alguns autores que há diferença entre o assediador e a assediadora. O homem assediador adota comportamentos mais passivos, isolando a vítima. Já a assediadora se utiliza de murmúrios e insinuações, embora esses comportamentos sejam utilizados pelos homens.(BARROS, 2009, p. 925)

Analisando esses perfis dos assediadores, concluímos que, seja homem ou mulher, o assediador é um monstro gerado pela realidade econômica e social que vivemos que provocam a ruína do ser humano, ou melhor, na vida do assediado ou sujeito passivo. 
b) Sujeito passivo: Não resta dúvida de que qualquer trabalhador pode sofrer o assédio moral, porém não há como excluir a existência de alguns coletivos que apresentam maiores possibilidades de virem a sofrer essa espécie de violência, na forma em que se apresentam mais e importantes debilidades perante o mercado de trabalho e na mesma empresa. São grupos ou coletivos com maior grau de vulnerabilidade, cujos empecilhos de acesso ao emprego ou para serem promovidos aos cargos mais elevados costumam ser maiores do que para o resto do grupo.

Esses conjuntos são figurados, por exemplo, pelas mulheres, pelos trabalhadores estrangeiros, por aqueles que são contratados por tempo determinado ou que sofrem qualquer incapacidade. É óbvio que esses grupos não exaurem os que conjuntamente possam também ser vítima do assédio moral, por causa da sua bastante vulnerabilidade, como os idosos, os negros, os homossexuais e outros segmentos que até mesmo, em face do preconceito, têm sido as essenciais vítimas da discriminação e de maltrato, inclusive pelos próprios colegas.(BARROS, 2008, p. 75)

A respeito das mulheres, ainda que estejam incluídas no mercado de trabalho, elas sofrem a diferenciação salarial mais do que os homens, e os obstáculos que encaram para promoção aos postos superiores são mais elevados em relação aos trabalhadores masculinos, sem mensurar que são elas que mais, concorrentemente, sofrem o assédio sexual. E muitas vezes quando se opõem a esse tipo de violência passam a ser vítimas de outra espécie de assédio, o assédio moral, transformando a sua conservação no posto de trabalho intolerável

Com relação aos estrangeiros, existem fatores que são potencialmente favoráveis ao Assédio Moral, entre os quais se destacam, as exigências legais para que estes trabalhadores, possam trabalhar em outro País serem maior do que aquelas existentes em relação aos nacionais, levando-os a submeterem a tarefas menos nobres e tratamentos contra a sua dignidade como a única forma de sobrevivência; e por último, quando se encontram em situação irregular em qualquer país, não tendo nem mesmo a proteção dos órgãos de fiscalização das condições de trabalho, uma vez que, em virtude do medo de perder o próprio emprego e serem mandados de volta à sua pátria, de onde muitas vezes foram expulsos pela fome, pela miséria, por guerras, perseguições políticas ou religiosas sequer denunciam os atos de violência dos quais são vítimas.

No que se refere aos temporários ou contratados por tempo certos, são particularmente suscetíveis e vulneráveis ao assédio, porquanto, a incerteza do vínculo pode 
constituir um importante elemento de destruição das relações laborais e, portanto, é mais simples de ser criado o clima de intimidação psicológica, quase sempre invisível, pois é o fim do contrato e não o abandono do posto de trabalho por parte da vítima do assédio, que finaliza a relação laboral.

Os trabalhadores com algum tipo de incapacidade, aqueles que retornam do seguro previdenciário em razão do acidente de trabalho ou doença ocupacional, gozam de um período de garantia do emprego e constantemente voltam com sua capacidade laborativa reduzida não tendo condições de manterem a mesma produção que tinham antes do sinistro, mas apesar disso, não podem ser despedidos a não ser por justa causa, art. 118 da Lei 8.213/91. Assim, em certas situações, eles passam a ser maltratados para que se desliguem voluntariamente da empresa.

Os idosos também são vítimas potenciais do assédio moral. Isso se deve a flexibilidade dos trabalhadores a novas situações e funções, e que os idosos costumam resistir com mais veemência do que os jovens, tornando-os mais vulneráveis ao assédio moral para que se demitam ou se aposentem, onde a empresa fica livre mais rapidamente e sem maiores custos.

No que tange aos negros e homossexuais, continuamente são vítimas do assédio moral com fundamento no preconceito, todavia, a sociedade apesar de propagar a igualdade, o respeito à diversidade e ao pluralismo, o que, além disso, está disposto na própria Constituição Federal, ${ }^{1}$ na prática permanecem excluindo e discriminando aqueles que por vários motivos, até mesmo, em face da cor da pele e da orientação sexual, não se encaixam no padrão atuante e isso acontece também e essencialmente no ambiente de trabalho.

Desse jeito, um dos elementos que melhor representa um processo de Assédio Moral é, sem sombra de dúvida, o preconceito. Ele se inicia com a discriminação em razão de

${ }^{1}$ Arts. $1^{\circ}$. A República Federativa do Brasil, formada pela união indissolúvel dos Estados do Distrito Federal, constitui-se em Estado Democrático de Direito e tem como fundamentos:

$[\ldots]$

IV - os valores sociais do trabalho e da livre iniciativa;

[...] Art. $3^{\circ}$ Constituem objetivos fundamentais da República Federativa do Brasil:

$[\ldots]$

IV - pomover o bem de todos, sem preconceitos de origem, raça, sexo, cor, idade e quaisquer outras formas de discriminação.

$[\ldots]$

Art. $5^{\circ}$ Todos são iguais perante a lei sem distinção de qualquer natureza, garantindo-se aos brasileiros residentes no País a inviolabilidade do direito à vida, à liberdade, à igualdade à segurança e à propriedade,nos termos seguintes: CÉSPEDES, Lívia; PINTO, Antonio Luiz de Toledo; WINDT, Márcia Cristina Vaz dos Santos. VadeMecum. 5. ed. atual. e ampl. -São Paulo: Saraiva, p. 7. 
diferenças visíveis como o sexo, a opção sexual, a cor da pele e outras, mas pode ter origem também em diferenças não tangíveis pelos demais.

Marie-France Hirigoyen (2010, p.80) procurou enumerar as sete pessoas propensas a sofrer Assédio Moral, acima colocadas, em vários grupos, que de um modo geral, são aquelas que revelam certo incômodo para outra pessoa ou para a harmonia do grupo.

As primeiras seriam as pessoas atípicas, isto é, aquelas que são portadoras de certos caracteres que as diferenciam do padrão dominante, como a cor da pele, o sexo, a orientação sexual.

O segundo grupo seria as pessoas demasiadamente competentes ou que apoderam de muito espaço, na medida em que sua personalidade poderá atrapalhar. Portanto, a vontade de afastá-las e livra-las é algo constante.

Aquelas que não se deixam conduzir e resistem a serem formatadas, configuram o terceiro grupo, como os empregados quem têm uma elevada honestidade, caráter e dinâmica, porque incomodam os atípicos que costumam afastá-los por suporem que essas pessoas apresentem defeito de adaptabilidade ao grupo ou à estrutura da organização.

Também, tem o quarto grupo que são os que não conseguem boas alianças ou uma boa rede de relacionamentos, tendo em vista que o assédio por ser um fenômeno patológico da sociedade costuma incidir com mais frequência sobre os trabalhadores isolados, enquanto aquele que tem aliados, o agressor a eles se unem, para romper o vínculo de solidariedade mantido com a vítima para que, ficando isolada, possa mais facilmente ser agredida, dominada e sacrificada.

Adiciona-se, ainda, o quinto tipo de pessoa, os assalariados protegidos, como as mulheres grávidas e aqueles que têm alguma garantia de emprego, como os que são garantidos por algum tipo de estabilidade. Já que não podem ser despedidos se não quando cometerem alguma falta de natureza grave, estão especialmente sujeitos a serem vítimas do assédio moral, fundamentalmente do serviço público onde a despedida do trabalhador é mais difícil e por isso, nesse setor o assédio moral além de bastante comum, costuma durar mais tempo e consequentemente acarretar maiores sequelas às suas vítimas.

As pessoas menos eficazes, sexto grupo de pessoas propensas a serem vítimas do Assédio Moral, visto que quando o trabalhador não é muito competente ou demora demais a se acostumar ao padrão empresarial, torna-se presa fácil de um processo de assédio, 
especialmente quando tem qualquer proteção, circunstâncias em que os próprios colegas acabam o isolando e mais tarde rechaçando-o.

O sétimo e último grupo é das pessoas com debilidade temporária, uma vez que são mais simples de serem judiadas por direções negligentes que delas precisam se livrar e com este objetivo, lançam mão do assédio moral porque essas vítimas raramente se defendem por possuírem dificuldades.

É irrefutável que os grupos acima enumerados são mais suscetíveis ao assédio moral, essencialmente quando concorrem na mesma pessoa mais de um dos tipos singulares dispostos, o que, entretanto, não designa assegurar que o restante dos trabalhadores tenham uma capa protetora contra o assédio moral.

Não se pode contestar, todavia, que os grupos anteriormente colocados são mais pendentes a padecer assédio moral, o qual autoriza assegurar que unicamente políticas ativas de prevenção e de erradicação dessa espécie de conduta junto com medidas educativas e de elucidação a respeito dos malefícios que elas provocam a toda à sociedade, especialmente ao próprio empresário, poderão proteger o trabalhador em desfavor desse tipo de violência.

\subsubsection{Elemento objetivo: conduta típica.}

Pela própria explicação adotada para o fenômeno do assédio moral, o comportamento do agressor que, além de complexas e variadas formas de expressão, destacase como um dos elementos integrantes da conduta ilícita do agressor.

Esse procedimento é revelado por atos de ofensa e inimizade, ou de comunicação adversa, sem ética e de caráter reprovável, por isso mesmo, deve ser objeto de condenação em termos morais, da forma em que presume, sob a perspectiva individual, uma falta de respeito à pessoa agredida acarretando, como acima destacado, uma perda de respeito à pessoa que dela é sofredora, e sob a visão coletiva, uma destruição inaceitável da relação social.

Hádassa Dolores (2004, p. 64) enumera os vários comportamentos que o sueco Heinz Leymann concluiu em sua pesquisa. Segundo a autora, inicialmente ele ressaltou em seu Leymann Inventory of Psychological Terrorization (Lipit) quarenta e cinco procedimentos distintos do Assédio Moral. Entretanto, no desfecho à sua pesquisa, reduziu-as em cinco: impossibilitar uma comunicação adequada com a vítima, recusando a comunicação direta; 
isolar a vítima; atacar a reputação da vítima; degradar as condições de trabalho e atacar a saúde da vítima com efetiva violência.

A recusa na comunicação direta, procura desmantelar a vítima, porque, eliminando a conversa ela ficará sem a solução sobre a procedência da conduta que recebe. Como coloca a psicóloga, a comunicação perversa tem como objetivo impedir o outro de pensar, de compreender, de reagir (HIRIGOYEN, 2010, p.75). Leymann relata que com esse procedimento o agressor intenta silenciar a vítima, às vezes agredindo-a verbalmente, exibindo desaprovação e descaso.

Essa técnica de relacionamento (HIRIGOYEN, 2010, p.75) funda-se no tratamento com desdém, no qual o empregador ou superior hierárquico não se comunica abertamente com a vítima, não a saudando, simulando, inclusive, sua inexistência. Chegando ao extremo de só se dirigirem por bilhetes ou boatos, acarretando o segundo tratamento que é o isolamento.

O isolamento é a atividade mais habitual no sistema do assédio moral. Alice Monteiros de Barros o expressa da seguinte forma:

[...] são atribuídas à vítima funções que a isolam ou deixam-na sem qualquer atividade, exatamente para evitar que mantenha contato com os colegas de trabalho e obtenha deles a solidariedade ou manifestação de apoio.(BARROS, 2008, p.919)

A essa altura, os colegas de trabalho estão cercados de tal forma pelo processo que acabam aprovando o tratamento que a vítima recebe, porventura pelo temor ou até mesmo pela cumplicidade, procedendo de forma igual. Para isolá-la, o superior hierárquico, despoja a vítima de informações importantes, não lhe avisando das reuniões que serão efetuadas, ou, acima de tudo, não lhe transmitindo o serviço que deveria realizar, colocando o empregado, na mira do assédio moral, inútil no trabalho.

As condutas individualizadas de comunicação direta e do isolamento, são desempenhadas suplementarmente, podendo revelar as seguintes, conforme Hirigoyen:

A vítima é interrompida constantemente. Superiores hierárquicos ou colegas não dialogam com a vítima. A comunicação com ela é unicamente por escrito. Recusam todo contato com ela, mesmo o visual. É posta separada dos outros. Proíbem os colegas de lhe falar. Já não o deixam falar com ninguém. A direção recusa qualquer tipo de entrevista. (HIRIGOYEN, 2010, p.113) 
Existem também as chamadas "técnicas de ataque" que consistem em colocar em dúvida a competência da vítima, inclusive sua sanidade, para que seja suprida sua autoconfiança. $\mathrm{O}$ assediador desqualifica e desacredita a vítima. A forma de desqualificar a vítima, é indireta, ao passo que, para desacreditar, o agente assediador humilha e ridiculariza a vítima, efetuando instigações com relação à etnia, gênero sexual, religião ou traços físicos da vítima, configurando esse tipo de tratamento uma violação à dignidade do trabalhador.

Pode acontecer também a deterioração das condições do trabalho, isto é, para atribuir à vítima a incompetência da tarefa o agressor recusa as informações, o material de trabalho e ainda as condições físicas para a execução do trabalho, podendo persistir até que a vítima se demita ou, caso isso não ocorra, até que ele encontre subterfúgio para isso.

A doutrina de Alice de Barros, cita algumas atitudes padrões tomadas pelos superiores hierárquicos, que acabam com as condições de trabalho:

[...] conferir à vítima tarefas de grande complexidade para serem executadas em curto lapso de tempo, com o fim de demonstrar a sua incompetência ou exigir-lhes tarefas absolutamente incompatíveis com a sua qualificação funcional e fora das atribuições de seu cargo. (BARROS, 2008, p.919)

Enfim, como uma conduta descomedida, o assédio moral pode atingir a violência física, verbal ou sexual. A violência, geralmente, compõe-se no derradeiro comportamento praticado pelo agente agressor, já que o Assédio Moral é perceptível por todos. A pesquisadora francesa ressalta como violência imediata os subsequentes atos:

Ameaça de violência física. Agridem-na fisicamente, mesmo que de leve, é empurrada, fecham-lhe a porta na cara. Falam com ela aos gritos. Invadem sua vida privada com ligações telefônicas ou cartas. Seguem-na na rua, é espionada diante do domicílio. Fazem estragos em seu automóvel. É assediada ou agredida sexualmente (gestos ou propostas). Não levam em conta seus problemas de saúde. (HIRIGOYEN, 2010, p.108)

Há, no entanto, outras maneiras de assediar moralmente uma pessoa, de forma disfarçada impossibilitando a contestação da vítima. São exprimidas por suspiros e posterior levantar dos ombros, por olhares de indiferenças, apreciações sinuosas, implícitos malignos, escárnio, sussurros, burburinho sobre a vítima, deboche, gozação e diversos golpes 
desestruturantes, habitualmente com plateia. Sem esquecer da discriminação, calúnias, difamações, injúrias, mentiras, rumores sobre preferências, favores sexuais que são, da mesma forma, técnicas usadas para caracterizar a conduta típica do agente assediador.

\subsubsection{Elemento teleológico: intenção lesiva do agressor.}

Todos os atos levados a um resultado pelo agressor, desligado de seu objetivo real e de sua maior ou menor capacidade ofensiva acham-se preestabelecidos a alcançar um objetivo: o de danos à vítima e, consequentemente, esses danos atingem diretamente um setor de sua personalidade.

Conforme a concepção objetiva, a intencionalidade do agressor não presume um elemento constitutivo do Assédio Moral, visto que apesar de ser óbvio que sua operação visa uma finalidade, a mesma pode abranger, além da destruição da vítima e sua exclusão, à destruição da organização ou da empresa.

Assim, qualquer que seja o propósito do agressor, há de se aceitar a existência do assédio moral no ambiente laboral no instante em que se produzam condutas contra a dignidade da pessoa, capaz de levar a um dano e sejam feitas de forma reiterada, independente de qual tenha sido a intenção que mantenha o agressor. Por conseguinte, o conceito do assédio moral é ampliado a outros elementos de violência física que tenha a meta diferente de deterioração da vítima, tratando de atitudes atentatórias à dignidade do trabalhador e que, segundo Lima Filho (2007, p.210), concorra, com o resto dos elementos do assédio moral.

Desta forma, encontra-se o assédio moral mesmo que o agressor não queira destruir ou expulsar a vítima da organização ou da empresa, tendo em vista que a conduta agressiva deve ser levada a efeito no ambiente de trabalho ou em decorrência deste de forma continuada e por um determinado lapso temporal com ofensa à dignidade do trabalhador, já que, na maioria dos casos esse tipo de agressão sempre provoca danos de ordem moral ou psíquica e até mesmo física que são bens integrantes da dignidade humana.

\subsection{Elemento organizacional: contexto sociolaboral}

O contexto laboral tem grande significado para o discernimento do assédio, na medida em que é preciso que, quem cometa as condutas de agressão tenha a condição de trabalhador da empresa, porque em grande parte dos casos o assediante e a vítima estão na 
mesma esfera, seção ou departamento empresarial, se bem que, não seja impraticável o assédio por terceiros os quais podem, mesmo, não pertencendo formalmente à empresa integrar o mesmo ambiente laboral, como ocorre, por exemplo, com o pessoal das prestadoras de serviços.

O comum é que tanto o agressor como a vítima pertençam ao quadro de pessoal da empresa, o que prova a importância do elemento organizacional para o reconhecimento do assédio, possibilitando até, a distinção com outras atitudes que, embora constituam uma violência contra o empregado, não caracterizam a figura ora analisada.

O progresso do assédio moral dentro da empresa, muitas vezes, adota certas características que sempre se ligam com a sua política de gestão, além do mais, a empresa carrega a responsabilidade de eleger seus superiores - quase sempre compostos por cargos de confiança - o que leva a entender como uma assunção do perigo de aquele superior hierárquico vir a ser ou não um agente assediador.

Hádassa Dolores descreve duas características da empresa, que a psicóloga francesa Marie-France Hirigoyen coloca como uma influência para o surgimento do assédio moral. A primeira característica destacada pela psicóloga é o incentivo à rivalidade entre os empregados, desempenhado pela própria empresa mediante seus prepostos. A própria empresa incita o certame entre os jovens e os mais velhos, inexperientes e experientes, estudados e autodidatas. Sobre tal, ela comenta:

A rivalidade é uma alavanca de que as empresas se servem, bastante cinicamente para se livrar de alguém incômodo: joga-se uma pessoa contra a outra, a fim de que uma delas decida pedir as contas (HIRIGOYEN, 2010, p.41)

A utilização do medo dos trabalhadores diante do desemprego por intermédio de ameaças de demissões fundamenta outra característica do assédio moral, também registrada por Hirigoyen. A atual organização do trabalho encoraja diversas empresas a instituir um método medonho sobre seus empregados, método esse que termina por produzir uma completa suspeita, uma autêntica disputa de todos contra todos, na qual é necessário agredir para não ser agredido.

Nesse feitio, não se pode de forma alguma abandonar a monta do contexto laboral na distinção de uma conduta específica de assédio moral, até mesmo para diferenciá-la de outras 
que, apesar de atípicas, não se misturam com aquelas que integram os elementos identificadores do assédio moral.

\subsubsection{Classificação do assédio moral no trabalho.}

As diferentes relações estabelecidas entre os sujeitos do assédio moral dão origem a três classificações do mesmo: assédio moral na linha descendente, ou assimétrica; assédio moral na linha horizontal, ou simétrica; e assédio moral na linha ascendente.

O assédio moral na linha descendente, ou assimétrica é a mais habitual, na qual o fenômeno advém da hierarquia. No interior dessa convivência os motivos que influenciam o assediador são diversos, segundo pontua Hirigoyen: há a finalidade pura e simples de exterminar a vítima para aumentar o próprio poder (do agressor); há também a meta de conduzir a vítima a requerer a demissão, o que acabaria com os custos extraordinários e coibiria procedimentos judiciais; e, além do mais, encontra-se a peculiar gestão da empresa que instiga e aceita o assédio moral como instrumento para governar seus empregados. (HIRIGOYEN, 2010, p.112)

Ainda sobre o assédio moral na linha descendente, Marco Aurélio Aguiar Barreto(2007, p.53), não esquece de dois bastantes fatores para a sua classificação, que são o abuso de poder empregado contra algum subordinado que não tenha afinidade com esse chefe, ou não obstante, quando este assediado demonstra - posto que, as vezes nem saiba - uma intimidação àquele chefe que busca arrasá-lo como mecanismo de extinguir um ficto adversário ou coloque em risco sua colocação ou as suas aspirações de elevação na estrutura da empresa.

O assédio moral pode ser classificado, ainda, na linha horizontal, ou simétrica, no momento em que o assédio é desenvolvido entre os colegas. Hirigoyen (2010, p.113) salienta que normalmente essa categoria ocorre no instante que dois empregados concorrem um cargo ou promoção igual e Hádassa também destaca outros fatores relevantes para configurar o Assédio Moral, dentre elas, a competição, a preferência pessoal do chefe porventura gozada pela vítima, a inveja, o racismo, a xenofobia e motivos políticos (FERREIRA, 2004, p.51). Em um grupo já consolidado, a entrada de um recente integrante pode desenvolver o desagrado daquele que, até o instante, dominava o grupo e abastecia a pretensão de ser nomeado para a chefia logo que vagasse. Marco Aurélio dispõe as atitudes que esse assediador faz para excluir o recente colega: 
[...] passa a manipular as pessoas; fazer intrigas veladas; sorrateiramente enaltecer as falhas do concorrente com o intuito de "queimálo" junto a administração; fazer concessões e agrados aos colegas a fim de angariar mais confiança; promover encontro sociais e não convidar o concorrente como forma de evitar aproximação deste com o grupo em ambiente extra trabalho, etc (BARRETO, 2007, p.53).

Uma última classificação que pode ser observada é o assédio moral na linha ascendente, ou seja, no momento em que um superior hierárquico é assediado por um ou mais subordinados. A circunstância pode não ser ordinária, mas acontece, como ilustra Hirigoyen (2010, p. 16) em face de enganosa denúncia de assédio sexual, ou, até mesmo quando toda uma equipe se junta para se opor a um superior hierárquico indesejado, ou por derradeiro, caso um pretensioso subordinado exerça malignamente e maleficamente certo comando sobre o grupo, ao pretender o cargo ocupado pelo seu chefe, pode com astúcia engendrar as pessoas de maneira que desarme a equipe, junte sua liderança e abafe a pessoa do chefe a ponto de conduzi-lo à demissão ou aposentadoria, ou inclusive, alimentar sua depressão por ser excluído do grupo, segundo Barreto (2007, p. 53).

\section{CRIME DE PERSEGUIÇÃO: CONSIDERAÇÕES SOBRE A SUA APLICAÇÃO NO ASSÉDIO MORAL.}

\subsection{CONSIDERAÇÕES INICIAIS}

A Lei 14.132/21 inseriu no Código Penal o Art. 147-A, denominado "crime de perseguição". Essa perseguição prevista no tipo penal, em inglês, stalking, significa perseguição contumaz e obsessiva. Em outros países o crime de perseguição já integra a legislação crimininal como na Itália, por exemplo.

Salvo se o fato constitui crime mais grave, é punido com reclusão de um ano a seis anos e seis meses quem, reiteradamente, ameaça ou perturba alguém causando-lhe um permanente e grave estado de ansiedade ou medo, ou produzindo-lhe um fundado temor pela própria incolumidade, de um parente próximo ou de pessoa com quem mantém relação afetiva, ou constrangendo-lhe a alterar sua própria rotina - Art. 612-bis.(CUNHA, 2021) 
Em Portugal, também há uma legislação anti-stalking, a Lei no 83/2015, de 05 de agosto :

Artigo $154 .^{\circ}-\mathrm{A}$

Perseguição por qualquer

1 - Quem, de modo reiterado, perseguir ou assediar outra pessoa,

meio, direta ou indiretamente, de forma adequada a provocar-lhe medo ou inquietação

ou a prejudicar a sua liberdade de determinação, é punido com pena de prisão até 3

anos ou pena de multa, se pena mais grave não lhe couber por força de outra

disposição legal.

2 - A tentativa é punível.

3 - Nos casos previstos no n. ${ }^{\circ} 1$, podem ser aplicadas ao arguido as penas

acessórias de proibição de contacto com a vítima pelo período de 6 meses a 3 anos e de

obrigação de frequência de programas específicos de prevenção de condutas típicas da

perseguição.

4 - A pena acessória de proibição de contacto com a vítima deve incluir o

afastamento da residência ou do local de trabalho desta e o seu cumprimento deve ser

fiscalizado por meios técnicos de controlo à distância.

5 - O procedimento criminal depende de queixa.(GOMES, 2021,

As duas legislações citadas de Itália e Portugal foram editadas após a ratificação da Convenção do Conselho da Europa para a Prevenção e Combate à Violência contra as Mulheres e a Violência Doméstica, vulgarmente conhecida por Convenção de Istambul. Desta, forma no Brasil não foi diferente, o ato de perseguição acontece com muita frequência em situações de violência doméstica e familiar contra a mulher, no entanto, o tipo penal previsto no art. 147-A não restringiu sua aplicação ao ambiente familiar, podendo ser aplicado em qualquer local, conforme será analisado no próximo tópico.

\subsection{STALKING OCUPACIONAL}

No Brasil o novo tipo penal não restringiu a sua aplicação ao ambiente doméstico e familiar, ou seja, os sujeitos do crime podem ser quaisquer pessoas, não se exigindo do sujeito ativo qualquer característica especial e do sujeito passivo determinou que se a vítima é 
criança, adolescente, idoso ou mulher perseguida por razão da condição do sexo feminino, a pena é aumentada de metade, trata-se de uma majorante, prevista no art. 147-A, $\S 1^{\circ}$ do Código Penal.

Para a configuração do tipo penal de perseguição o agente tem que perseguir alguém, reiteradamente e por qualque meio, segundo Rogério Sanches o verbo perseguir tem a seguinte conotação:

O verbo perseguir não tem apenas a conotação de ir freneticamente no encalço de alguém. Há também um sentido de importunar, transtornar, provocar incômodo e tormento, inclusive com violência ou ameaça. É principalmente com essa conotação que se tipifica a conduta de perseguir no art. 147-A.(CUNHA, 2021)

A conduta de perseguir tem uma conotação bem abrangente, podendo ser entendida como importunar, transtornar, provocar incômodo e tormento que atinja a vítima de três formas: a) ameaçando a integridade física ou psicológica; b) restringindo a capacidade de locomoção; c) invadindo ou perturbando a esfera de liberdade ou privacidade.

$\mathrm{Na}$ primeira forma, há uma ameaça por meio de palavras, gestos ou atitudes ostensivas que provocam na vítima um estado de ansiedade tão perturbador que o estado emocional da vítima abala-se. É nesta forma que poderia-se afirmar que há uma tutela jurídica ao stalking ocupacional ou assédio moral laboral, pois, segundo Rogério Sanches:

Há inúmeros casos em que a fixação "doentia" se inicia entre pessoas que não tinham qualquer relação afetiva. São os casos de colegas de estudo ou de trabalho, do empregado que, dispensado, passa a perseguir o empregador, ou do empregador que, por alguma razão, persegue o empregado provocando sua demissão ou impedindo-o de conseguir outro emprego (stalking ocupacional).(CUNHA, 2021)

A partir desta primeira forma e se adotar a concepção objetiva dos elementos constitutivos do conceito de Assédio Moral, apontados acima por Lima Filho, como a prática reiterada de violência psicológica no contexto sociolaboral para a configuração do Assédio Moral Laboral, o crime de perseguição emglobaria o Assédio Moral, inclusive, as suas diversas modalidades: o ascendente, o descendente e horizontal.

\section{CONSIDERAÇÕES FINAIS}


O assédio moral, apesar de ser um fenômeno que sempre existiu nas relações humanas, é um assunto que, sobretudo nas relações de trabalho, somente na última década, ganhou destaque nas discussões doutrinárias. Diante de sua importância e relevância nas relações de trabalho, médicos, psicólogos, administradores, profissionais juslaborais e sindicatos, em nível mundial, começaram a voltar seus estudos para esse grave fenômeno, demonstrando a preocupação de diversas áreas do conhecimento, para com a efetiva tutela dos interesses das pessoas envolvidas nessa relação. No entanto, a discussão sobre o tema ainda é tímida, a despeito da existência do fenômeno em larga escala.

Essa violência perversa que ameaça o meio ambientes de trabalho, como acima relatado, através de uma pesquisa às legislações, percebeu-se que não tínhamos nenhuma legislação federal que a punisse penalmente, senão alguns projetos de lei relevantes, que, inclusive, a definem de maneira mais completa como no Projeto de Lei n. 4.742 de 2001, cujo conceito de assédio moral abrange todos os elementos constitutivos do conceito de assédio moral, conforme a classificação objetiva, que adotou-se nesta pesquisa.

Para finalizar, conclui-se que, para que haja um meio ambiente do trabalho equilibrado psiquicamente, há a possibilidade de aplicação do crime de perseguição à perseguição provocada pelo Assédio Moral.

\section{REFERÊNCIAS BIBLIOGRÁFICAS.}

ALKIMIN, Maria Aparecida. Assédio Moral na Relação de Emprego. Curitiba: Juruá, 2005

BARRETO, Marco Aurélio Aguiar. Assédio Moral no Trabalho uma responsabilidade do empregador- perguntas e respostas. 1. ed.São Paulo: LTr, 2007.p.53.

BELTRAMI, Gisele Caversan. PALMA, Cláudio Sanches. O assédio moral como norma penal incriminadora. Intertemas Vol. 13, N. 13, 2007. Disponível em: http://intertemas.toledoprudente.edu.br/revista/index.php/Juridica/article/view/513/509 Acesso em: 06 jul 2015 p. 78

BRASIL, Projeto de Lei n. 4.742 de 2001. Introduz art. 146-A no Código Penal Brasileiro - Decret0 Lei n. 2.648, de 7 de dezembro de 1940 - dispondo sobre o crime de assédio moral no 
http://imagem.camara.gov.br/Imagem/d/pdf/DCD26MAI2001.pdf\#page=74 Acesso em: 06 jul 2015

CARVALHO, Gisele Mendes de, CARVALHO, Érika Mendes de O assédio moral nas relações de trabalho: uma proposta de criminalização Disponível em: http://www.publicadireito.com.br/conpedi/manaus/arquivos/anais/brasilia/05_841.pdf Acesso em: 13 abril 2019

CUNHA, Rogério Sanches. Lei 14.132/21: Insere no Código Penal o art. 147-A para tipificar o crime de perseguição. Disponível em: https://meusitejuridico.editorajuspodivm.com.br/2021/04/01/lei-14-13221-insere-no-codigopenal-o-art-147-para-tipificar-o-crime-de-perseguicao/ Acesso em 14 abr 2021

FERREIRA, Hádassa Dolores Bonilha. Assédio Moral nas Relações de Trabalho. 1. ed. Campinas: Russel Editores, 2004

GARCIA CALLEJO, José Maria. Protección jurídica contra elacoso moral em el trabajo o la tutela de ladignidad del trabajador. Madrid: Federación de Servicios Públicos de UGT Madrid

GOMES, Filipa Isabel Gromicho. O novo crime de perseguição: considerações sobre a necessidade de intervenção penal no âmbito do stalking. Dissertação de mestrado em Direito (Ciências Jurídico-Criminais), apresentada à Faculdade de Direito da Universidade de Coimbra. 2016 Disponível em: http://hdl. handle.net/10316/41675 Acesso em: 15 abril 2021

HIRIGOYEN, Marie-France. Mal-Estar no trabalho: redefinindo o Assédio Moral. Trad. Rejane Janowitzer. 5 ed. Rio de Janeiro: Bertrand Brasil, 2010

LEYMANN, Heinz. The mobbingencyclopedia. Disponível em: www.leymann.se/English/frame.html Acesso em: 09 nov. de 2015.

LIMA FILHO, Francisco das Chagas. O assédio moral nas relações laborais e a tutela da dignidade humana do trabalhador. São Paulo: LTr, 2009

PAMPLONA FILHO, Rodolfo. Noções conceituais sobre o assédio moral na relação de emprego. Jus Nvigandi, Teresina, ano 10, n. 1.149, 24 ago. 2006. Disponível em: http://jus2.uol.com.br/doutrina/texto.asp?id=8838. Acesso em: 29 jul.. 2015 